\section{INDIVIDUALNI I KONTEKSTUALNI ČINITELJI DJEČJEGA NASILNIČKOGA PONAŠANJA PREMA VRŠNJACIMA}

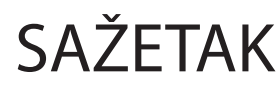

Vršnjačko nasilničko ponašanje je sve učestalija pojava među djecom i predstavlja značajan društveni problem. Mnogobrojna istraživanja ove pojave objašnjenja su potražila u klasičnim teorijama agresivnosti koje vršnjačko nasilje tumače kao jedan od oblika agresivnog ponašanja. Ipak, novija istraživanja sve više teoretsko polazište pronalaze u novijim i sveobuhvatnijim integrativnim modelima nasilnog ponašanja ujedinjujući $i$ kombinirajući veći broj čimbenika iz klasičnih teorija i bolje doprinose objašnjenju pojave nasilničkog ponašanja prema vršnjacima. Jedna od najčešće primjenjivanih integrativnih teorija je Bronfenbrennerov ekološki model koji je potaknuo niz istraživanja bihevioralnih, psiholoških i bioloških karakteristika pojedinaca, ali i interakcija između pojedinca i njegove okoline te interakcije između konteksta na različitim razinama. $U$ ovom se radu na temelju opsežnog pregleda literature, a pod vidom ekološkog modela, pokušavaju usustaviti do sada utvrđene spoznaje o čimbenicima koji su povezani

\footnotetext{
1 Doc. dr.sc. Tena Velki, psihologinja, e-mail:tena.velki@gmail.com

2 Prof.dr. sc. Gordana Kuterovac Jagodić, psihologinja, e-mail: gkuterov@ffzg.hr
}

Pregledni članak

Primljeno: srpanj, 2013.

Prihvaćeno: ožujak, 2014.

UDK 159.97-053.2

DOI 10.3935/ljsr.v21i1.11

\section{Tena Velki ${ }^{1}$}

Učiteljski fakultet

Sveučilište J. J. Strossmayer u

Osijeku

\section{Gordana}

Kuterovac Jagodić ${ }^{2}$

Filozofski fakultet

Sveučilište u Zagrebu

Ključne riječi:

vršnjačko nasilje, ekološki model, individualne karakteristike, kontekstualne karakteristike. 
s pojavom nasilničkog ponašanja među vršnjacima te dati kritički osvrt na ta istraživanja s posebnim naglaskom na ona koja su bila rukovođena ekološkim pristupom. Premda se primjećuje značajan pomak u primjeni teorijskih okvira i unapređenju metodologije i složenijih postupaka analize podataka, vrlo mali broj studija pri provođenju istraživanja vršnjačkog nasilja uzima u obzir veći broj činitelja i aspekata okoline. Većina istraživača usmjerava se na jednu ili dvije razine ekološkog modela i jednostavniju metodologiju, zanemarujući pritom složenost ove problematike. Buduća istraživanja trebala bi pri planiranju i provedbi uzeti u obzir nove teorijske, ali i metodološke spoznaje na ovom propulzivnom području.

\section{UVOD}

Vršnjačko nasilničko ponašanje zabrinjavajuća je pojava među djecom i predstavlja značajan društveni problem jer ga prema istraživanjima vrši oko 3 do 27 , a trpi oko 9 do 32\% školske djece (Stassen Berger, 2007.; Sušac, Rimac i Ajduković, 2012.). Nasilničko ponašanje među djecom povezano je $s$ brojnim problemima mentalnoga zdravlja u djece i adolescenata, kako internaliziranim tako i eksternaliziranim (Gini i Pozoli, 2009.), kao i sa sniženim školskim uspjehom (Glew i sur., 2005.). Vršnjačko se nasilje može kategorizirati na različite načine. Prema vrsti nasilnih akata razlikuje se najčešće tjelesno i verbalno nasilničko ponašanje, prema tome koliko je ponašanje vidljivo, razlikuje se otvoreno i skriveno ili relacijsko, a prema tome je li spontano ili izazvano, može se razlikovati proaktivno i reaktivno nasilničko ponašanje (Griffin i Gross, 2004.). U novije se vrijeme govori i o elektroničkom nasilju koje se kao otvoreno ili skriveno vrši putem elektroničkih sredstava komuniciranja. Djeca uključena u nasilničko ponašanje obično se prema ulozi koju u njemu imaju svrstavaju u tri kategorije: nasilnici - djeca koja samo čine nasilničko ponašanje nad vršnjacima, pasivne žrtve - djeca koja samo trpe nasilničko ponašanje te počinitelji nasilnici-žrtve - djeca koja vrše nasilje nad drugima, ali i sama trpe nasilničko ponašanje. Prema tom se obrascu uloga često istražuju, uspoređuju i vrednuju čimbenici i posljedice nasilničkog ponašanja po djecu. Nasilničko ponašanje prema vršnjacima označava se i drugim terminima kao što su vršnjačko nasilje, agresivnost ili vršnjačko zlostavljanje. Kako spomenuti termini nisu sinonimi, prilikom istraživanja i rasprave o nasilju među djecom potrebno je jasno definirati o kojem se ponašanju radi. Vršnjačko zlostavljanje je posebno pakostan oblik agresivnog ponašanja koji karakteriziraju opetovani akti nasilja prema slabijoj žrtvi koja se teško može obraniti (Rigby, 2002.). Vršnjačko zlostavljanje (engl. bullying) ima tri distinktivne karakteristike: postoji nerazmjer u moći nasilnika i žrtve, po- 
stoji namjera nasilnika i ponašanje nije jednokratno nego se ponavlja. Vršnjačko zlostavljanje često se neopravdano poistovjećuje s vršnjačkim nasiljem (engl. peer

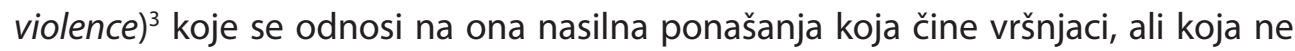
uključuju nužno sve navedene distinktivne karakteristike, tj. ne postoji nesrazmjer moći nasilnika i žrtve, namjera počinjenog nasilničkog ponašanja nije jasna i ono ne mora predstavljati obrazac ponašanja (Rajhvajn Bulat i Ajduković, 2012.). Ovaj rad bavi se čimbenicima koji su povezani s problematikom činjenja vršnjačkog nasilja u ovim širim terminima.

Prvotna istraživanja problematike vršnjačkog nasilja za njega su objašnjenje tražila u okviru teorija agresivnosti, kao što su biološke i frustracijske teorije agresivnosti, teorije učenja agresivnog ponašanja te kognitivističke teorije (Orpinas i Horne, 2006.b). Međutim, kako niti jedna pojedinačna teorija nije dala zadovoljavajuće objašnjenje ovog složenog fenomena, u novije se vrijeme javljaju kompleksniji i sveobuhvatniji integrativni modeli agresivnog ponašanja. Jedan od najčešće istraživanih integrativnih modela je Bronfenbrennerov ekološki model razvoja, koji omogućuje holistički pogled na problem vršnjačkog nasilja i viktimizacije. Kako ovaj model omogućuje lakše grupiranje i kategoriziranje potencijalnih čimbenika te donošenje pretpostavki o putovima njihova međudjelovanja, u posljednje vrijeme autori usustavljuju čimbenike nasilničkog ponašanja upravo iz te perspektive (npr. Hong i Espelage, 2012.; Sabri i sur., 2013.). Prema ekološkom pristupu, nasilničko se ponašanje djece može objasniti rizičnim čimbenicima u nekoliko sustava koji dijete okružuju i na njega djeluju izravno i neizravno. Osim spomenutih sustava i individualni čimbenici, odnosno psihološke i biološke karakteristike djeteta, utječu na to hoće li ono sudjelovati u nasilju i u kojoj ulozi (Espelage i Swearer, 2004.). Djetetove interakcije s članovima obitelji, prijateljima, vršnjacima, nastavnicima i drugima iz njegovog neposrednog okružja, uključujući tu i nasilne interakcije kao i reakcije drugih na vršnjačko nasilje, predstavljaju čimbenike mikrosustava. Međusobne interakcije mikrosustava obitelji, škole i vršnjaka tvore mezosustav koji također ima izravan utjecaj na pojavu ili izostanak vršnjačkog nasilja (Swearer, Espelage i sur., 2010.). Osim neposrednih utjecaja, posredan utjecaj na pojavu nasilja i viktimizacije imaju i od djeteta udaljeniji sustavi poput uže društvene zajednice, susjedstva i medija (egzosustav), ali i kultura i državna politika (makrosustav). Pretpostavlja se kako ti distalni sustavi na dijete djeluju preko nižih razina sustava koji pak funkcioniraju kao medijatori.

Ciljevi ovog rada su na temelju opsežnog pregleda literature, a pod vidom ekološkog modela, usustaviti do sada utvrđene spoznaje o čimbenicima koji su

${ }^{3}$ U daljenjem tekstu termin vršnjačko zlostavljanje (engl. bullying) i vršnjačko nasilje (engl. peer violence) koristit će se onako kako su ih upotrijebili autori izvornih referenci. 
povezani s pojavom nasilničkog ponašanja među vršnjacima te dati kritički osvrt na ta istraživanja s posebnim naglaskom na ona koja su bila rukovođena ekološkim pristupom. Prilikom razmatranja relevantne literature, izdvojeni su oni čimbenici koji se posebno ističu u predviđanju nasilničkog ponašanja nad vršnjacima, a mogu se teorijski svrstati na pojedine razine ekološkog modela.

\section{INDIVIDUALNI ČINITELJI NASILNIČKOG PONAŠANJA PREMA VRŠNJACIMA}

\section{Demografske značajke djeteta}

Spol i dob su najistraživanije individualne dječje osobine povezane s nasilnim ponašanjem. Ranija istraživanja pokazala su kako su dječaci više tjelesno nasilni (Espelage, Bosworth i Simon, 2000.), dok su rezultati istraživanja spolnih razlika u verbalnom nasilju manje konzistentni (Knight i sur., 2002.). U novije vrijeme sve se više istražuje relacijsko nasilje (npr. isključivanje iz društva; osujećivanje tuđih veza, i sl.; Wang, lannotti i Nansel, 2009.) gdje su prvotna istraživanja pokazala kako djevojčice češće koriste relacijski oblik vršnjačkog nasilja nego dječaci (Crick i Bigbee, 1998.). Međutim, novija istraživanja, kao i metaanalize pokazuju kako je muški spol značajan prediktor samo fizičkog nasilja, dok se čini kako relacijsko nasilje nije svojstvenije djevojčicama nego dječacima (Card i sur., 2008.). Premda se spolne razlike očekuju i objašnjavaju na različitim razinama, od biološke prema kojoj je slabija fizička snaga žena uzrok tome da se one moraju koristiti indirektnijim oblicima nasilja (Björkqvist, 1994.), do socijalizacijske prema kojoj roditelji potkrepljuju izravne oblike nasilnog ponašanja kod dječaka, a obeshrabruju kod djevojčica te se one zato moraju služiti skrivenijim oblicima agresivnog ponašanja (Underwood, 2003., prema Cardi sur., 2008.), one mogu proizlaziti i iz metodoloških karakteristika istraživanja.

Tako jedan od metodoloških izvora spolnih razlika može biti način postavljanja pitanja o učestalosti pojedinih oblika nasilja. Ukoliko se o relacijskom nasilju djecu ne pita bez postavljanja preduvjeta o ljutnji (npr. »Kada si ljut, koliko često ignoriraš drugu djecu?«), tada se pokazuje kako su dječaci podjednako nasilni ili čak i nasilniji od djevojčica (Olweus, 2010.). Metoda prikupljanja podataka također može rezultirati različitim spolnim razlikama u nasilnom ponašanju dječaka i djevojčica. Archer (2004.) je u velikoj metaanalizi istraživanja djece i odraslih utvrdio da žene pokazuju veću indirektnu agresivnost kada se koriste metode opažanja, procjene vršnjaka i procjene nastavnika, dok se takve razlike ne nalaze kada se koriste metoda vršnjačke nominacije ili samoizvještavanje. Card i sur. (2008.) u svojem metaanalitičkom istraživanju pokazuju kako razlike mogu biti vezane i uz izvor podataka.

\section{6 članci}


Kada se za procjenu izravne agresivnosti koriste samoizvještaji i roditelji, tada se nalaze manje spolne razlike nego kada izravnu agresivnost procjenjuju vršnjaci. Također, u procjenama indirektne agresivnosti roditelji i nastavnici procjenjuju da su djevojčice nešto agresivnije od dječaka, dok su prema samoprocjenama dječaci indirektno agresivniji od djevojčica. Spolne razlike u nekim drugim osobinama, kao što je, primjerice, empatija, također mogu igrati ulogu u spolnim razlikama u nasilnom ponašanju prema vršnjacima. Naime, utvrđeno je kako djevojčice pokazuju viši stupanj empatične brige za tuđe osjećaje što bi ih trebalo učiniti manje sklonima nasilju (Özkan i Gökçearslan, 2009.).

Može se zaključiti kako je potreban oprez u donošenju zaključaka o spolnim razlikama u nasilnom ponašanju među vršnjacima jer one mogu biti metodološki artefakti. No s druge strane, nasilničko ponašanje dječaka i djevojčica može biti jednake učestalosti, no imati različite korijene. Tako je Velki (2012.) utvrdila kako su za nasilno ponašanje prema vršnjacima za dječake važniji prediktori roditeljski odgojni postupci, a za djevojčice osjećaj roditeljske brige i prihvaćenosti od strane roditelja i vršnjaka.

Nalazi oko povezanosti dobi i nasilja među vršnjacima naizgled nisu jednoznačni. U Bergenskoj je studiji utvrđeno kako je $50 \%$ osnovnoškolske djece koja su bila izložena nasilju vršnjaka to doživjela od djece koja su od njih bila starija (Olweus, 1998.). Slične rezultate dobili su i autori u Hrvatskoj koji su pokazali kako najviše nasilničkog ponašanja pokazuju učenici završnih razreda osnovne škola (Buljan Flander, Ćorić Špoljarić i Durman Marijanović, 2007.). Ta i slična istraživanja ukazuju na porast nasilnog ponašanja s dobi, no neki su utvrdili i suprotno, tj. kako s porastom dobi djeteta dolazi do smanjenja nasilja (Espelage i Horne, 2008.). Takva razmimoilaženja u rezultatima proizlaze iz dijela dobne krivulje koji se ispituje jer čini se kako porast nasilničkog ponašanja s dobi nije linearan, nego ima oblik obrnute U- krivulje (Olweus, 1998.). Tijekom osnovnoškolske dobi dolazi do porasta nasilničkog ponašanja te je ono najučestalije kod djece u završnim razredima osnovne i nižim razredima srednje škole, dok poslije toga slijedi pad. Vrhunac vršnjačkog nasilja, posebice relacijskog, zabilježen je u dobi od 14-15 godina (MurrayHarvey, Slee i Taki, 2010.; Sušac, Rimac i Ajduković, 2012.). Porast nasilnosti u višim razredima osnovne škole kao i u početnim razredima srednje škole objašnjava se pokušajem djece, a posebice dječaka, da putem nasilja uspostave dominantni status u grupi (Pellegrini i Long, 2002.; Vejmelka, 2012.). Kako se učenici bliže završetku srednjoškolskog obrazovanja, nasilništvo se smanjuje što se može objasniti učenjem socijalno prihvatljivijih oblika ponašanja, boljom emocionalnom regulacijom, ozbiljnijim sankcijama koje starija djeca snose za agresivno i nasilno ponašanje. Prave odgovore na pitanje izvora dobnih promjena mogu dati samo dugotrajnija longitudinalna istraživanja nasilnog ponašanja. 
Od ostalih demografskih značajki djece ispituju se još rasna ili etnička pripadnost kao i socioekonomski status o kojem će biti riječi u poglavlju o mikrosustavu obitelji. Istraživanja o tome jesu li pojedine etničke skupine djece sklonije biti žrtvama nasilničkog ponašanja ili biti nasilnici, ne pokazuju dosljedne rezultate. Tako je, primjerice, u nekim istraživanjima utvrđeno kako su američka djeca azijskog i hispano-latinskog podrijetla češće žrtve vršnjačkog nasilja (Peguero, 2009.), dok su druga istraživanja pokazala kako su djeca euroameričkog podrijetla češće od ostalih bile žrtve vršnjačkog nasilja (Hanish i Guerra, 2000.). Čini se kako je učestalost zlostavljanja uvjetovana kontekstom, tj. udjelom manjinske djece u razredu, školi ili zajednici općenito (Espelage i Swearer, 2003.). Također, upravo je etnička ili rasna pripadnost u heterogenim dječjim zajednicama ona koja često uvjetuje sadržaj vršnjačkog nasilja pa su tako ta djeca izrugivana zbog svojeg izgleda, jezika, običaja i sl. Prema našim spoznajama, u Hrvatskoj nije izravno ispitivana varijabla etničke pripadnosti kao faktor rizika za vršnjačko nasilje iako se može pretpostaviti kako bi ona mogla to biti, osobito u zajednicama koje su bile jače izložene ratnim stradanjima i u kojima je utvrđena sklonost djece da diskriminiraju pripadnike druge etničke skupine (Ajduković i Čorkalo Biruški, 2008.).

\section{Ostale individualne karakteristike djeteta}

Neke psihološke značajke djece, neki njihovi emocionalni problemi, kao i zdravstveni status također mogu biti činitelji koji ih čine sklonijima upuštati se u nasilno ponašanje nad vršnjacima ili biti žrtve takvog ponašanja.

Nedostaci u empatičkim emocijama ili suosjećajnom ponašanju pokazali su se povezanima s različitim oblicima antisocijalnog ponašanja i eksternaliziranim oblicima psihopatologije (Espelage, Mebane i Swearer, 2004.). Istraživanja su pokazala kako počiniteljima vršnjačkog nasilja nedostaje empatije, ali se povezanost između nedostatka empatije i nasilja među djecom razlikuje u dječaka i djevojčica (Espelage, Mebane i Swearer, 2004.). Djevojčice izvještavaju općenito o višoj razini empatije, uključujući emocionalnu (npr. empatična briga oko osjećaja drugih) i kognitivnu komponentu (npr. zauzimanje stava prema tuđim osjećajima). Dobivena je slaba negativna povezanost između razine nasilnosti i razine empatije i to za oba spola. Osim toga, djeca s većom razinom empatične brige (afektivna komponenta) nasilničko ponašanje prema vršnjacima procjenjuju negativnije, a i sama čine manje nasilja od djece s manjom razinom empatičke brige (Espelage, Mebane i Swearer, 2004.; Gini i sur., 2007.). Počinitelji nasilja-žrtve također pokazuju manje brižnog ponašanja i manje osjetljivosti prema emocijama drugih, isto kao i počinitelji nasilja, što upućuje na deficit u afektivnoj komponenti empatije kod nasilne djece općenito (Espelage, Mebane i Swearer, 2004.).

\section{8 članci}


Stavovi i vjerovanja o nasilju pokazali su se kao dobri prediktori vršnjačkog nasilja. Počinitelji nasilja agresiju smatraju uobičajenim obrascem ponašanja (Marini, Dane i Bosacki, 2006.), očekuju uspjeh kada se njome koriste i ne očekuju negativne posljedice zbog vlastitog nasilnog ponašanja (Perry, Williard i Perry, 1990.). Djeca vrtićke i mlađe školske dobi općenito pokazuju više negativnih stavova i vjerovanja o nasilju, dok pri ulasku u adolescenciju ti stavovi postaju sve manje negativni, što je i u skladu s porastom nasilnog ponašanja s porastom djetetove dobi tijekom adolescencije (Aluede i sur., 2008.). Prvotna istraživanja nasilnog ponašanja usmjerila su se na specifične komponente rješavanja problema za koje se pretpostavlja da postoji deficit kod nasilne djece. Djeca počinitelji nasilja motivirana su nasilnim namjerama, imaju vjerovanja koja podupiru nasilje, nisu u stanju predvidjeti posljedice nasilničkog ponašanja, biraju puno manje neagresivnih alternativa kada trebaju riješiti problem, nedostaje im samopouzdanja kada trebaju koristiti nenasilne strategije te zbog svega navedenog dolaze do neefikasnih rješenja (Orpinas i Horne, 2006.a). Istraživanja su pokazala da i počinitelji nasilja-žrtve također imaju deficit u vještinama rješavanja problema, čak i veći od počinitelja nasilja (Cassidy i Taylor, 2005.). Počinitelji nasilja i počinitelji nasilja-žrtve, kada se nalaze izloženi stresnoj situaciji, koriste destruktivne strategije rješavanja problema (Stevens, De Bourdeaudhuij i Van Oost, 2002.). Međutim, kasnija istraživanja, posebice ona usmjerena na relacijske i neizravne oblike nasilja zastupaju objašnjenje u skladu s teorijom uma (Shakoor i sur., 2012.). Prema ovoj teoriji, počinitelji nasilja nemaju deficite u rješavanju problema, nego zapravo vrlo dobro razumiju druge osobe i njihove slabosti, pa tako znaju odabrati žrtve za koje nije vjerojatno da će dobiti potporu vršnjaka, kao i specifičan oblik nasilja koji je prikladan da povrijedi upravo tu izabranu žrtvu. Ipak, postoje istraživanja koja nisu utvrdila da djeca koja čine nasilno ponašanje imaju razvijenije vještine socijalne kognicije od ostalih skupina uključenih u nasilno ponašanje (Givens, 2009.). Ova kontradiktorna objašnjenja rezultat su različite operacionalizacije počinitelja nasilja, gdje treba razlikovati nasilne vođe, počinitelje nasilja-žrtve te počinitelje nasilja koji samo slijede nasilne vođe. Iz navedenog se može zaključiti kako za nasilnu djecu koja su vođe vjerojatno vrijedi da oni posjeduju određene dobro razvijene socijalne vještine pri čemu znaju dobro odabrati žrtvu i situaciju u kojoj će činiti nasilje te u kojoj će imati podršku druge djece i sljedbenike koji će im se priključiti (što je u skladu s teorijom uma). Za razliku od njih, počinitelji nasilja koji su ujedno i žrtve i počinitelji nasilja koji samo slijede nasilne vođe vjerojatno češće imaju deficit u socijalnim vještinama i u vještinama rješavanju problema pa u skladu s tim koriste neprilagođene, često destruktivne strategije rješavanja problema.

Internalizirani emocionalni problemi poput depresivnosti i anksioznosti također igraju ulogu u nasilničkom ponašanju. Istraživanja su utvrdila simptome de- 
presivnosti kod svih sudionika nasilnog ponašanja bez obzira na njihov status (npr. Majvald Bjedov, 2011.). Najveći rizik za razvoj depresije i za suicid imali su počinitelji nasilja-žrtve. Počinitelji nasilja-žrtve pokazali su najvišu razinu depresivnih simptoma, čak veću nego žrtve (Swearer i sur., 2001.). Istraživanja su pokazala značajnu povezanost između anksioznosti i verbalnog i tjelesnog nasilja (Kashani, Dueser i Reid, 1991.). Za neku djecu anksioznost može predstavljati slabost koju pokušavaju kompenzirati nasiljem prema vršnjacima. Također, anksioznost povećava djetetovu osjetljivost na znakove opasnosti u interpersonalnim situacijama što opet vodi k češćim nasilnim reakcijama. Istraživanja su pokazala kako nasilna anksiozna djeca krivo interpretiraju neutralne situacije kao prijeteće i zbog toga nasilno reagiraju (Barrett i sur., 1996.). Najviša razina anksioznosti konzistentno je pronađena kod počinitelja nasilja-žrtvi nasilja (Duncan, 1999.; Swearer i sur., 2001.). Ipak, potrebna su dodatna longitudinalna istraživanja kako bi se utvrdilo prethode li anksioznost i depresivnost pojavi nasilničkog ponašanja ili se javljaju kao njegova posljedica, ili je pak taj odnos još složeniji pa neke druge varijable također posreduju u toj povezanosti.

Općenito su istraživanja pokazala kako su hiperaktivna djeca, posebice ona s izraženom impulzivnošću, često uključena u vršnjačko nasilje (Aluede i sur., 2008.). Impulzivna djeca imaju nizak prag na frustraciju, pa često neprikladno nasiljem reagiraju u neutralnim situacijama (Olweus, 1994.). Djeca koja uz to još imaju i motoričke smetnje, poteškoće u učenju te koja su imala ozljede glave i perinatalne komplikacije rizičnija su za razvoj nasilja i delinkvencije (Buka i Earls, 1993.).

Očigledna različitost djece po nekim karakteristikama izgleda i sposobnosti čini se da također nose povećan rizik za sudjelovanje u nasilnom ponašanju. Tako je utvrđeno kako djeca s povećanom tjelesnom težinom i pretila djeca imaju povećan rizik da budu žrtvama nasilnog vršnjačkog ponašanja, ali i da sama budu počinitelji nasilja (Kukaswadia, 2009.). Djeca s očiglednim razvojnim teškoćama i teškoćama u učenju također su rizičnija za to da budu žrtvama vršnjačkog nasilništva zato što su često pasivna, imaju teškoća u shvaćanju odnosa i u komunikaciji s vršnjacima te zato i ograničene socijalne vještine što ih čini rizičnima za postajanje žrtvama ili nasilnicima-žrtvama (Rose, Monda-Amaya i Espealage, 2011.).

Djetetove intelektualne sposobnosti pokazuju zanimljivu povezanost $\mathrm{s}$ nasilnim ponašanjem: u riziku za bivanje žrtvom vršnjačkog nasilnog ponašanja su kako djeca sniženih intelektualnih sposobnosti i nižeg školskog uspjeha (npr. Saylor i Leach, 2009.), tako i djeca koja pokazuju natprosječne intelektualne sposobnosti i iznimna akademska postignuća (Woods i Wolke, 2004.) Ovi potonji su prvenstveno žrtve relacijskog nasilja (nazivanje pogrdnim imenima, isključivanja iz društva, zadirkivanje zbog uspjeha ili izgleda), ali određeni broj njih sudjeluje i samo u vršenju nasilja (Peterson i Ray, 2006.), što je u skladu s nalazima prema

\section{0 članci}


kojima su neki nasilnici posebno socijalno vješti i inteligentni te mogu manipulirati pomagačima u nasilnom ponašanju i znalački odabirati najosjetljivije žrtve.

Može se zaključiti kako mnoge individualne značajke djece, osobito one koje ih čine perceptivno istaknutima prema izgledu, sposobnostima ili pripadnosti manjinama (pretilost, vidljive razvojne teškoće i invaliditet, boja kože i sl.), ili pak iznimno ranjivima (snižena inteligencija, anksioznost, depresivnost) predstavljaju rizične čimbenike za izloženost nasilju od strane vršnjaka. S druge strane, one značajke koje ih čine manje osjetljivima na tuđu nevolju i potiču da na neodgovarajući način komuniciraju s vršnjacima (slabija empatija, hiperaktivnost, nedostatak socijalnih vještina i rješavanja problema) češće ih potiču na neadekvatna i nasilna ponašanja i/ili pak izazivaju nasilje prema njima.

\section{MIKROSUSTAV I DJEČJE NASILNIČKO PONAŠANJE: OBITELJ, VRŠNJACI I ŠKOLA}

Mikrosustav u Bronfenbrennerovom modelu uključuje one okolinske čimbenike razvoja s kojima je dijete u izravnoj interakciji i koji izravno utječu na njegov razvoj, a najvažniji od tih čimbenika su obitelj, vršnjaci i škola. Kada se radi o nasilničkom ponašanju, tada su važne reakcije mikrosustava i čimbenika unutar njih na vršnjačko nasilje. Nakon osobina samog djeteta, mikrosustav obitelji je najistraživaniji ekološki sustav kada se radi o vršnjačkom nasilju.

\section{Obitelj}

Obitelj je primarna okolina u kojoj dijete odrasta te ima ključnu ulogu u mnogim aspektima dječjeg razvoja. Istraživanja pokazuju kako sama struktura obitelji, odnosi članova obitelji, kao i roditeljska ponašanja i drugi procesi u obitelji igraju važnu ulogu u nasilničkom ponašanju djece.

Od strukturalnih čimbenika jednoroditeljske se obitelji ističu kao rizični čimbenik za nasilno ponašanje. Nasilna djeca češće nemaju oca ili je on odsutan, a upravo se nedostatak oca za dječake pokazao rizičnim činiteljem za razvoj nasilničkog ponašanja (Espelage, Bosworth i Simon, 2000.), dok život u dvoroditeljskoj obitelji može biti zaštitni faktor protiv nasilničkog ponašanja (Spriggs i sur., 2007.). Značajan čimbenik je i kvaliteta odnosa među roditeljima. Naime, u obiteljima nasilne djece majke su češće izolirane i permisivne, dok očevi imaju puno veću moć u obitelji od njih (Curtner-Smith, 2000.). Iz sličnih obitelji dolaze i počinitelji nasilja koji su ujedno i žrtve jer neka istraživanja pokazuju kako oni češće imaju majke koje pokazuju ljutnju te nemaju autoritet u obitelji (Stassen Berger, 2007.). 
Kvaliteta odnosa i povezanosti članova iz koje dolaze djeca uključena u nasilno ponašanje također je narušena. Općenito, nasilna djeca dolaze iz obitelji koje su manje kohezivne i u kojima su roditelji slabo uključeni u djetetove aktivnosti, posebice majke (Berdondini i Smith, 1996.). U obiteljima nasilne djece prevladava negativna emocionalna klima, a posebice nedostatak empatije i modela za osjećajno ophođenje s drugima (Olweus, 1994.), kao i roditeljske emocionalne socijalne podrške (Demaray i Malecki, 2003.). Djeca počinitelji nasilja-žrtve izvještavaju o najmanje roditeljske podrške, o više disharmonije unutar obitelji te općenito o slabijoj uključenost roditelja u njihove aktivnosti (Ahmed i Braithwaite, 2004.; Bowes i sur., 1994.). Posebno je pogubna djetetova izloženost svađama, sukobima i nasilju među roditeljima jer je utvrđena povezanost djetetove izloženosti nasilju s povećanim rizikom kako za činjenje nasilnog ponašanja nad vršnjacima tako i za bivanje njegovom žrtvom (Cummings i Davies, 2002.). Baldry je (2003.) utvrdio kako djeca koja svjedoče nasilju unutar obitelji imaju 3 puta veću šansu postati počinitelji nasilja u školi, a Schwartz, Dodge, Pettit i Bates (1997.) da i počinitelji nasilja-žrtve vršnjačkog nasilja dolaze iz obitelji u kojima je prisutna agresija između roditelja. Istraživanja u Hrvatskoj u sklopu BECAN projekta (Sušac, Rimac i Ajduković, 2012.) pokazala su značajnu povezanost između počinjenog i doživljenog vršnjačkog nasilja sa svim oblicima obiteljskog nasilja (psihološka agresija, psihološko zlostavljanje, tjelesno kažnjavanje, tjelesno zlostavljanje i zanemarivanje).

Kvaliteta emocionalne privrženosti roditeljima značajan je čimbenik odnosa $s$ drugima tijekom čitavog života, pa tako utječe i na nasilne odnose s vršnjacima. Istraživanja pokazuju kako su nasilna djeca nesigurno privržena uz svoje roditelje (Kõiv, 2012.), posebice uz majku (Eliot i Cornell, 2009.). Čini se kako djeca počinitelji nasilja-žrtve imaju najviši stupanj nesigurne privrženosti, a odmah iza njih djeca počinitelji nasilja (Nikiforou, Georgiou i Stavrinides, 2013.). Longitudinalna su istraživanja pokazala da kod djece počinitelja nasilja prevladava izbjegavajući nesigurni stil privrženost, gdje je ključna nekonzistencija u raspoloživosti majke (Rigby, 1993.). Izbjegavajući stil privrženosti prema majci pokazao se dobrim prediktorom relacijskog nasilja kod djevojčica, dok je isti stil privrženosti prema ocu dobar prediktor relacijskog nasilja kod dječaka (Williams, 2011.). Izbjegavajući stil privrženosti pronađen je također i kod počinitelja nasilja-žrtava (Kokkinos, 2013.). Može se pretpostaviti da nasilna djeca imaju teškoća u odnosu s vršnjacima kao rezultat unutarnjeg radnog modela sebe i drugih koji pretpostavlja Bowlbyjeva teorija privrženosti (Bowlby, 1979.). Tako je vjerojatno da nasilna djeca imaju negativan model drugih te ih percipiraju prijetnjom kada ona to i nisu i zato napadaju, ali i da imaju negativan model sebe jer pokušavaju nasilnim načinima ojačati svoje samopoštovanje i status u grupi. Slično tome, vjerojatno i djeca žrtve nasilničkog ponašanja imaju i negativan model samih sebe te tako postaju podložna nasilju druge djece.

\section{2 članci}


Nadalje, utvrđeno je kako u obiteljima nasilne djece postoje problemi u komunikaciji roditelja i djece (Nansel i sur., 2001.) koji se očituju u nedovoljnom komuniciranju, ili pak njezinoj poremećenoj kvaliteti. Naime, roditelji djece koja su nasilna uglavnom nameću svoju moć i mišljenje bez obrazloženja što je posebice problematično kada komuniciraju s djetetom o rizičnim i problematičnim ponašanjima (Berthold i Hoover, 2000.).

Roditeljski stil koji se odnosi na emocionalnu dimenziju odnosa prema djetetu, kontrolu djetetova ponašanja i način discipliniranja pokazuje snažnu povezanost roditeljskih ponašanja s djetetovom ulogom u vršnjačkom nasilju. Autoritaran roditeljski stil najbolji je prediktor nasilničkog ponašanja u djeteta (Baldry i Farrington, 2000.). Veenstra i sur. (2005.) utvrdili su da su počinitelji nasilja-žrtve i počinitelji nasilja, za razliku od žrtava i djece neuključene u nasilje, imali roditelje kojima je nedostajala toplina u odgoju i koji su ih često odbijali. Roditelji počinitelja nasilja-žrtava u svom odgoju često primjenjuju indiferentni roditeljski stil odgoja, odnosno zanemaruju djecu i u odgoju primjenjuju nedosljednu disciplinu, dok roditelji djece počinitelja nasilja imaju autoritaran roditeljski stil odgoja (Bowers, Smith i Binney, 1994.). Način discipliniranja djece pokazao se kao važan čimbenik u pojavi nasilničkog ponašanja. U obiteljima djece nasilnika tjelesno kažnjavanje i pretjerana upotreba moći najčešći su načini uspostavljanja discipline (Schwartz i sur., 1997.; Shields i Cicchetti, 2001.). Za razliku od njih, obitelji počinitelja nasiljažrtava često su previše zaštitničke (Bowers, Smith i Binney, 1994.; Schwartz i sur., 1997.). Osobito je pogubno discipliniranje koje je zlostavljajuće jer najviše nasilničkog ponašanja (tjelesnog i verbalnog nasilja) pokazuju djeca iz zlostavljajućih obitelji (Knutson, 1995.). Zlostavljajući roditelji češće vide svoju djecu kao agresivnu, namjerno neposlušnu i koja namjerno dosađuju, čak i kada drugi tako njihovu djece ne percipiraju (Cicchetti i Cohen, 2006.). Takvi roditelji razvijaju neadekvatna očekivanja od djeteta te često koriste neprikladnu disciplinsku praksu, a kazne koje koriste nisu u skladu s djetetovom dobi. Tako djeca unutar obitelji uče kako je agresija prikladan način rješavanja sukoba i to naučeno ponašanje prenose $u$ odnose s vršnjacima. Zbog toga što pokazuju visok stupanj agresivnog ponašanja, manje empatije i prosocijalnog ponašanja, zlostavljana djeca češće doživljavaju odbacivanje vršnjaka (Buljan Flander, Ćorić Špoljarić i Durman Marijanović, 2007.; Cicchetti i Cohen, 2006.). Zanemareni dječaci pokazuju najviše nasilničkog ponašanja i problema u socijalizaciji, za razliku od djevojčica koje najviše nasilja i problema u socijalizaciji pokazuju ukoliko su bile tjelesno zlostavljane (Knutson, 1995.).

Značajan broj istraživanja bavio se i utjecajem braće/sestara na razvoj nasilničkog ponašanja među djecom. Djeca koja u obitelji imaju nasilne odnose s braćom/sestrama češće su uključena u vršnjačko nasilje u školi (Menesini, Camodeca i Nocentini, 2010.). Duncan (1999.) je utvrdio kako je oko 50 posto djece koja su bila 
nasilna u školi također nasilno prema braći/sestrama, dok je u skupini djece počinitelja nasilja-žrtava nasilničkog ponašanja prema vršnjacima njih čak više od tri četvrtine bilo nasilno prema braći/sestrama. Istraživanje Wolke i Skewa (2012.) pokazuje kako djeca počinitelji nasilja-žrtve među braćom/sestrama imaju dva puta veću vjerojatnost postati žrtvama vršnjačkog nasilja u školi.

Razina obiteljskog socioekonomskog statusa (SES), koja se najčešće operacionalizira preko varijabli prihoda obitelji, stupnja obrazovanja te zaposlenosti roditelja, negativno je povezana $s$ vršnjačkim nasiljem i viktimizacijom iako ta povezanost nije izravna (Eisenberg, Damon i Lerner, 2006.; Rivers, Duncan i Besag, 2007.). U obiteljima niskog SES-a siromaštvo povećava stres u roditelja što dovodi i do povećanja sukoba u obitelji, neadekvatnog roditeljstva ili čak zlostavljanja i zanemarivanja, te slabog nadzora djece što vodi povećanju nasilnosti i viktimizacije kod djece (Eisenberg, Damon i Lerner, 2006.). Međutim, budući da obitelji niskog SES-a često žive u opasnijim naseljima, teško je razdvojiti utjecaj opasnog susjedstva od utjecaja samog SES-a (Gullotta, Adams i Ramos, 2005.). Novija istraživanja pokazala su da je za predviđanje vršnjačkog nasilja od SES-a važnija nejednakost prihoda obitelji djece unutar škole koju dijete pohađa. Ukoliko su razlike u primanjima među obiteljima velike, javlja se više vršnjačkog nasilničkog ponašanja (Elgar i sur., 2009.).

\section{Škola}

Škola je važan mikrosustav u kojem djeca u interakciji s nastavnicima i vršnjacima, uz stjecanje formalnog znanja, oblikuju svoju sliku o sebi kao i o svijetu u kojemu žive. Čini se kako nastavnici nasilnoj djeci daju više negativnih i manje stabilnih povratnih informacija što posredno vodi i k lošijem školskom uspjehu (Orpinas i Horne, 2006.a). S druge strane, djeca koja zbog neuspjeha izostaju i na kraju odustaju od školovanja kasnije su sklonija nasilju i delinkvenciji. Utvrđena je negativna povezanost između uključenosti učenika u nasilje (bilo kao žrtve ili počinitelji nasilja) i školske kompetencije (Dake, Price i Telljohann, 2003.). Najslabiju školsku kompetenciju imaju žrtve nasilja dok počinitelji nasilja-žrtve i počinitelji nasilja imaju nešto bolju, ali podjednako slabu školsku kompetentnost i uspjeh (Dake, Price i Telljohann, 2003.; Nansel i sur., 2001.; Profaca, Puhovski i Luca Mrđen, 2006.). Školski neuspjeh pokazao se jakim rizičnim čimbenikom za razvoj nasilničkog ponašanja i agresije u tinejdžera i odraslih kao i za razvoj delinkvencije u muških adolescenata (Farrington, 1997.; Orpinas i Horne, 2006.a).

Negativni emocionalni odnos djeteta s nastavnicima povećava vjerojatnost javljanja nasilničkog ponašanja, posebice kod djece mlađe školske dobi (Hanish

\section{4 članci}


i sur., 2004.). Ukoliko nastavnici ne pružaju socijalnu podršku djeci i ne uključuju jednako svu djecu u razredne aktivnosti, bilježi se više nasilničkog ponašanja (Kasen i sur., 2004.; Newman, Murray i Lussier, 2001.). Slično je i u razredima gdje su nastavnici hladni i ne odgovaraju na djetetove potrebe (Olweus i Limber, 1999.) te nisu u stanju brzo i efikasno reagirati pri pojavi nasilja (Olweus, 1994.).

Škole koje ne pružaju učenicima dovoljno prilika za bliskiju interakciju s nastavnicima, gdje djeca ne razvijaju povezanost s školom i nastavnicima te škole u kojim se djeca ne osjećaju ugodno imaju negativnu školsku klimu, a ona je snažan prediktor uključenosti djece u nasilje i viktimizaciju (npr. Orpinas i Horne, 2006.a). Negativna školska klima, posebno njezin emocionalni aspekt, mjeren učeničkom percepcijom pripadnosti i/ili ugodnosti osjećanja u školi, povezana je s vršnjačkim nasiljem (Kasen i sur., 2004.). Općenito, počinitelji nasilja imaju negativnu percepciju škole, loš odnos s nastavnicima, loš školski uspjeh, češće bježe s nastave, ne osjećaju pripadnost školi te ne poštuju školska pravila (Harel-Fisch i sur., 2011.). Neka istraživanja pokazuju kako počinitelji-žrtve imaju najlošiju prilagodbu na školu i najslabije su s njome povezani (Ahmed i Braithwaite, 2004.; Harel-Fisch i sur., 2011.).

Nedostatak nadzora odraslih u školi važan je čimbenik za pojavu vršnjačkog nasilja jer se nasilje u školi najčešće događa na lokacijama gdje nastavnici nisu prisutni, npr. wc, hodnici, školsko igralište, blagovaonica i sl. (Buljan-Flander, Ćorić Špoljarić i Durman Marijanović, 2007.; Espelage i Swearer, 2004.; Velki, 2010.), te tijekom neakademskih aktivnosti (Card i Hodges, 2008.). Nastavnici u osnovnim školama, posebice u nižim razredima, češće nadziru djecu tijekom odmora te smatraju to dijelom svog odgojnog posla (Holt i Keyes, 2004.), dok stariju djece manje nadziru i manje su skloni uplitati se u njihove sukobe, posebice ako oni nisu fizičke prirode (O'Moore, Kirkham i Smith, 1998.). Međutim, nastavnici često nisu svjesni nasilja među djecom, ne znaju ga prepoznati niti ne reagiraju adekvatno kada je u pitanju vršnjačko nasilničko ponašanje (Hazler, Miller, Carney i Green, 2001.).

Politika škole vezana uz sprečavanje sukoba i nasilja također igra važnu ulogu u raširenosti nasilničkog ponašanja prema vršnjacima. Najbolja školska politika je ona koja aktivno traži rješenje problema vršnjačkog nasilja, koja uspostavlja jasna pravila ponašanja, mjere i kazne za nepoželjna ponašanja, te sve to dosljedno provodi u cijeloj školi, a ne ona koja samo kažnjava nasilnu djecu (Samara i Smith, 2008.). Suprotna politika ignoriranja i toleriranja nije djelotvorna jer se pokazalo da američke škole koje ne zabranjuju tjelesno kažnjavanje imaju značajno veću razinu vršnjačkog nasilja (Orpinas i sur., 2000.) te veći broj djece koja nose oružje u školu (Arcus, 2002.). Međutim, niti politika strogog i rigidnog reagiranja na disciplinske probleme, ali slabe prevencije i nedostatnog podučavanja učenika nenasilnim strategijama rješavanja sukoba, tako da učenici u situacijama nasilja ne znaju kako pravilno reagirati, nije se pokazala korisnom (Orpinas i Horne, 2006.a). 


\section{Vršnjaci}

Pripadnost vršnjačkim grupama vrlo je važna u kasnom djetinjstvu i ranoj adolescenciji jer djeca traže autonomiju od roditelja i podršku od prijatelja i vršnjaka (Espelage i Swearer, 2004.). Vršnjačko nasilje kod djece starije osnovnoškolske dobi i srednjoškolaca služi za uspostavu statusa, dominacije unutar grupe te osiguranje resursa (Vejmelka, 2012.). Djeca se češće druže s vršnjacima koji imaju slične interese i reputaciju pa tako i nasilna djeca oba spola imaju više prijatelja koji vole kršiti pravila (Dijkstra, Lindenberg i Veenstra, 2007.) i imaju pozitivan stav prema nasilju (Pellegrini, Bartini i Brooks, 1999.). Premda su ranija istraživanja pokazivala kako su počinitelji nasilja odbačeni od strane vršnjaka (Parkhurst i Hopmeyer, 1998.), novija istraživanja pokazuju kako nasilna djeca nisu socijalno izolirana, nego pronalaze prijatelje sličnih osobina i ponašanja, od kojih dobivaju podršku za svoje nasilničko ponašanje (Perren i Hornung, 2005.). U predškolskoj dobi nasilna su djeca češće odbačena, no u školskoj dobi odbacivanje se smanjuje (Snyder, Horsch i Childs, 1997.). Općenito, počinitelji nasilja doživljavaju manje odbacivanje od strane vršnjaka te su bolje prihvaćeni od počinitelji nasilja-žrtava nasilničkog ponašanja koje su manje prihvaćene, odnosno čak odbačene od strane vršnjaka (Perren i Hornung, 2005.).

Neka nasilna djeca su popularna (LaFontana i Cillessen, 2002.; Parkhurst i Hopmeyer, 1998.) zato jer zbog sposobnosti manipulacije svojom socijalnom okolinom postaju vođe unutar grupe vršnjaka (Sutton, Smith i Swettenham, 1999.), posebno u adolescenciji. Popularni počinitelji nasilja nameću vlastite vrijednosti te nasilno ponašanje biva tolerirano ili normativno za članove grupe (Rodkin, Farmer, Pearl i Van Acker, 2000.). Nasilni dječaci u adolescenciji djevojčicama postaju privlačni pa i to utječe na njihovu popularnost (Rodkin, 2002.). Za razliku od nasilnih dječaka, nasilne djevojčice su manje popularne, ali većinom kod agresivnih vršnjakinja, jer se njihova agresija ne smatra normativnim ponašanjem (Farmer i sur., 2002.).

Premda su istraživanja pokazala kako su nasilna djeca prihvaćena i mogu biti popularna unutar vršnjačkih grupa, to ne znači da su omiljena. Tjelesno i relacijski nasilni dječaci, a posebice djevojčice, nisu omiljeni u društvu (Cillessen i Borch, 2006.). Počinitelji nasilja-žrtve nasilja najmanje su omiljeni te imaju najviše problema u odnosima s vršnjacima (Marini, Dane i Bosacki, 2006.).

lako se mislilo da nasilnoj djeci nedostaje prijatelja, istraživanja su pokazala da oni imaju prijatelje, iako nešto manje nego djeca neuključena u nasilje (Snyder, Horsch i Childs, 1997.). Počinitelji nasilja imaju veći broj prijatelja nego žrtve, jer su obično prihvaćeni u grupama djece istog ponašanja dok počinitelji nasilja-žrtve nasilja imaju manji broj prijatelja posebice ako su skloni verbalnom i relacijskom obliku nasilničkog ponašanja (Wang, lannotti i Nansel, 2009.).

\section{6 članci}




\section{MEZOSUSTAV I DJEČJE NASILNIČKO PONAŠANJE}

Međusobne interakcije mikrosustava tvore mezosustav koji također ima izravan utjecaj na razvoj nasilja i viktimizacije (Swearer i sur., 2010.), a najčešće proučavani mezosustavi su interakcije obitelji i škole i interakcije obitelji i vršnjaka. Istraživanja su pokazala da uključenost roditelja u obrazovanje djeteta (dolasci na roditeljske sastanke i informacije, dolasci i/ili sudjelovanje na djetetovim školskim aktivnostima, zadovoljstvo školskim sustavom i sl.) igraju važnu ulogu u sprečavanju pojave vršnjačkog nasilja (Rumberger, 1995.). Kada se roditelji, nakon lošeg uspjeha djeteta, više uključe u njegovo obrazovanje, djeca pokazuju poboljšanje školskog uspjeha, općenito pozitivnije stavove prema školi, ali poboljšavaju i ponašanje (Kellaghan, Sloane, Alvarez i Bloom, 1993.). Osim toga, posebice kod mlađe djece, veliku ulogu ima i roditeljsko poznavanje i utjecaj na odabir vršnjaka s kojima se dijete druži. Roditelji koji poznaju prijatelje svoje djece, njihove obitelji i općenito koji više pokazuju interes za djetetove vršnjake imaju djecu koja pokazuju manje nasilničkog ponašanja (Orpinas i Horne, 2006.a). Premda mnogobrojni programi prevencije nasilja (Espelage i Swearer, 2004.) govore o važnosti suradnje roditelja i nastavnika i uključenosti roditelja u djetetov život, općenito nedostaje takvih istraživanja koja bi ispitala odnos ovih čimbenika i vršnjačkog nasilja. Novija istraživanja čije je polazište ekološki model pokazala su kako su interakcija permisivnosti roditelja i nastavnika (Barboza i sur., 2009.) te nejednakost obiteljskih prihoda unutar razreda koji učenik pohađa (Velki, 2012.) važni prediktori vršnjačkog nasilja s razine mezosustava. No, to su samo neki potencijalni čimbenici koji nam ukazuju na važnost istraživanja čimbenika s ove razine.

\section{EGZOSUSTAV I DJEČJE NASILNIČKO PONAŠANJE}

Život u zajednici s visokom razinom nasilja daje djetetu priliku za učenje agresivnih ponašanja, kako potkrepljivanjem postojećih negativnih ponašanja tako i mogućnošću priključivanja skupini delinkventnih vršnjaka, te izloženosti oružju (Marini, Dane i Bosacki, 2006.; Pettit i sur., 1999.). Nekoliko je američkih istraživanja pokazalo da je izloženost nasilju u zajednici potencijalni rizični čimbenik za razvoj nasilničkog ponašanja u školi (npr. Bradshaw i sur., 2009.; Gullotta, Adams i Ramos, 2005.). Istraživanja su također pokazala da povezanost između opasnosti susjedstva i nasilja u djece i adolescenata često nije izravna nego posredna, preko roditeljskog nadzora koji ima medijatorski učinak (Pettit i sur., 1999.). Ipak, ove nalaze s oprezom treba tumačiti u našoj kulturi, koja još nije dosegla stope ekstremnog kriminaliteta kao što je slučaj s američkom kulturom u kojoj su većinom provede- 
na navedena istraživanja. Bilo bi zanimljivo provjeriti utjecaj života u nekim našim specifičnim susjedstvima, npr. u gradovima i naseljima pogođenim Domovinskim ratom, gdje prevlada nesnošljivost različitih etničkih grupa ili u izrazito siromašnim susjedstvima, kao potencijalne prediktore vršnjačkog nasilja.

Osim zajednice, tradicionalni mediji (televizija, filmovi, glazba i dr.) i Internet imaju velik utjecaj na ponašanje djece jer su djeca putem njih izložena ogromnoj količini nasilja (npr. Ilišin, 2003.). Svakodnevno izlaganje nasilju u medijima može promijeniti stavove djece prema nasilju, podučiti ih nasilničkom ponašanju te smanjiti njihovu osjetljivost na nasilje, odnosno povećati toleranciju na njega. Izloženost nasilju putem televizije pokazalo se rizičnim čimbenikom za razvoj nasilničkog ponašanja prema vršnjacima (Zimmerman i sur., 2005.). Istraživanje u Sloveniji (Pšunder i Cvek, 2012.) utvrdilo je kako preko 50\% učenika (od četvrtog do osmog razreda osnovne škole) voli gledati nasilne programe (češće dječaci), te kako ih uglavnom gledaju bez nadzora odraslih. U novije se vrijeme sve više pažnje posvećuje i nasilju u kompjuterskim igrama koje najčešće igraju djeca osnovnoškolske dobi i starija (Woodward i Gridina, 2000.). Istraživanja (Gentile i sur., 2004.; Gentile i Walsh, 2002.) su pokazala da se u $89 \%$ kompjuterskih igara javlja nasilje, a u više od $50 \%$ kompjuterskih igara uključeno je ekstremno nasilje. Nadalje, ista istraživanja pokazala su da igranje nasilnih kompjuterskih igara povećava nasilničko ponašanje, povećava znanje o nasilju, povećava agresivne emocije, povećava psihološko uzbuđenje i smanjuje prosocijalno ponašanje kod djece i odraslih oba spola, te povećava vjerojatnost da će učenici biti uključeni u fizičke obračune s drugima i češće se svađati s učiteljima (Anderson i sur., 2004.; Gentile i Walsh, 2002. ). Roditeljsko ograničavanje igranja nasilnih kompjuterskih igara pozitivno djeluje na školski uspjeh i na smanjenje nasilničkog ponašanja u djece (Gentile i sur., 2004.). U novije vrijeme sve je učestaliji oblik vršnjačkog nasilja nasilje putem Interneta (eng. cyberbullying), te korištenje Interneta bez nadzora također predstavlja rizični čimbenik za razvoj vršnjačkog nasilja, ali i za viktimizaciju (Dooley, Pyzalski i Cross, 2009.). Utjecaj medija, igranja kompjuterskih igara i korištenja Interneta moderiran je roditeljskim nadzorom i primjenom stroge discipline u odgoju jer u obiteljima gdje roditelji nadziru dječje aktivnosti na kompjuteru i ograničavaju vrijeme i televizijski program koji dijete gleda, postoji manji utjecaj medija, kompjuterskih igara i korištenja Interneta na pojavu vršnjačkog nasilja (Eisenberg, Damon i Lerner, 2006.).

\section{MAKROSUSTAV I DJEČJE NASILNIČKO PONAŠANJE}

Premda se pretpostavlja kako kultura, odnosno supkultura unutar koje dijete odrasta ima također značajnu ulogu u razvoju nasilničkog ponašanja prema vrš-

\section{8 članci}


njacima, makrosusav je najmanje ispitivana razina ekološkog modela vršnjačkog nasilja. Šira zajednica, odnosno ekonomski uvjeti života, kulturalne norme i stavovi koji u njoj prevladavaju (o ulozi žene, obiteljskim ulogama, kažnjavanju djece, ciljevima odgoja i sl.) imaju distalni i posredni, ali značajan utjecaj na razvoj djetetovog ponašanja, pa tako i onog nasilničkog (Espelage i Swearer, 2004.).

Istraživanja su jasno pokazala da učestalost javljanja nasilničkog ponašanja ovisi o tome prevladava li u društvu individualizam ili kolektivizam (Nesdale i Naito, 2005.) te o društvenoj organizaciji (Laub i Lauritsen, 1998.). Istraživanje nasilničkog ponašanja u Australiji i Japanu pokazalo je kako japanski učenici imaju veću učestalost nasilničkog ponašanja od australskih učenika te su manje skloni pomoći žrtvi (Nesdale i Naito, 2005.). U kolektivističkom društvu, kada postoji osoba koja narušava grupne ciljeve, pravila i norme ili koja se po nečemu razlikuje od ostatka grupe, postoji velika vjerojatnost da će je grupa htjeti kazniti nasilnim ponašanjem, a to su pokazala i istraživanja nasilja među učenicima u Koreji (Park i Son, 1998.) i Japanu (Tai, 2001.). U razredima u kojima postoji grupno natjecanje i kolektivna kazna ima više nasilja jer su individualni ciljevi učenika u suprotnosti s grupnim ciljevima i raste vjerojatnost da učenik koji ima individualne ciljeve postane žrtva nasilničkog ponašanja. Istraživanja koja se baziraju na društvenoj organizaciji (Laub i Lauritsen, 1998.) pokazuju kako je pojava vršnjačkog nasilja učestalija u velikim gradovima i u područjima gdje prevladava socijalna dezorganizacija i izolacija (Shin, 2000.). Jedna od teškoće pri međukulturalnim usporedbama je to što zapadne kulture pod nasiljem češće podrazumijevaju izravne oblike nasilja, posebice tjelesno, dok istočne kulture češće pod nasiljem podrazumijevaju neizravne oblike nasilja, posebice relacijsko (Slee, 2003.).

\section{RASPRAVA}

Vršnjačko nasilničko ponašanje kompleksan je fenomen čije tumačenje zahtijeva jednako tako složen pristup te se Bronfenbrennerov ekološki model sve više koristi kao okvir za usustavljivanje rezultata mnoštva istraživanja na ovom području. Opsežnim pregledom istraživanja utvrđeno je kako je najveći broj provedenih istraživanja vršnjačkog nasilja, uz individualne čimbenike, ispitivao pojedine čimbenike ili grupe čimbenika s razine mikrosustava, osobito mikorsustava obitelji, škole i vršnjaka, dok su istraživanja čimbenika mezosustava, egzosustava, te posebice makrosustava mnogo rjeđa. Također, još je uvijek razmjerno malen broj istraživanja koja bi istodobno zahvaćala i ispitivala čimbenike s više različitih razina ovog modela. Neka takva istraživanja pojavila su se u zadnjih desetak godina, te su se usmjerila na provjeravanje ekološkog modela vršnjačkog nasilja kako bi što obu- 
hvatnije istražila čimbenike koji doprinose i utječu na pojavu nasilničkog ponašanja prema vršnjacima, posebice u školskom okruženju. Prva istraživanja primjene ekološkog modela na problematiku vršnjačkog nasilja provedena su u američkoj (npr. Barboza i sur., 2009.; Espelage i Swearer, 2004., 2009.a, 2009.b; Lee, 2010.) i azijskim kulturama (Khoury-Kasssabri i sur., 2004.; Lee, 2011.; Wei i sur., 2010.), a prema našim spoznajama, samo je jedno istraživanje u kojem je korišten ovaj model provedeno u našoj zemlji (Velki, 2012.).

Primjena ekološkog modela u istraživanju vršnjačkog nasilničkog ponašanja donijela je značajan pomak u teorijskoj artikuliranosti ovih istraživanja, u metodologiji istraživanja te u analizi podataka. Mjerenje vršnjačkog nasilničkog ponašanja ne vrši se više isključivo putem samoprocjena, nego se sve češće primjenjuju procjene od strane drugih značajnih osoba (npr. roditelja, vršnjaka, nastavnika) i sociometrijski postupci, a također su razvijeni i brojni instrumenti za mjerenje različitih korelata nasilničkog ponašanja. Značajan pomak primjećuje se i u korištenju statističkih analiza, koje su od početnih jednostavnijih analiza (npr. ANOVA i regresijska analiza) prerasle u složenije multivarijantne analize (npr. HLM i SEM). Sofisticiraniji statistički postupci dovode do poboljšanja razumijevanja problema jer omogućuju istovremeno ispitivanje velikog broja čimbenika te uz to uzimaju u obzir i njihovu međusobnu povezanost, odnosno njihove interakcije. Uzimajući u obzir međusobnu povezanost razina sustava, ova su istraživanja provjerila međuodnose čimbenika s različitih razina sustava, pozabavila se moderatorskim utjecajima i omogućila objašnjenje proporcije varijance s pojedinih razina sustava. Također, diferencirani su i prediktori za različite vrste vršnjačkog nasilja.

Spol se očekivano pokazao značajnim moderatorom te je utvrđeno kako vršnjačko nasilje kod dječaka i djevojčica predviđaju različiti čimbenici. Tako su se za dječake boljim prediktorima pokazale biološke (npr. dob) i roditeljske varijable (npr. kažnjavanja, nadzor), a za djevojčice osjećaji prihvaćenosti (roditeljske i vršnjačke) i školske ocjene (Velki, 2012.). Značajan je i moderatorski učinak školske klime pri čemu je pozitivna školska klima povezana s manje vršnjačkog nasilja kod djece kojima nedostaje roditeljske brige i koji su pod negativnim utjecajem vršnjaka (Espelage i Swearer, 2009.a) te kod dječaka koji žive u opasnim susjedstvima (Velki, 2012.). Nadalje, moderatorski utjecaj ima i vrijeme provedeno gledajući televiziju, percepcija opasnosti susjedstva, roditeljsko znanje o djetetovim aktivnostima i roditeljski nadzor. Više vremena provedeno u gledanju televizije povezano je s većom vjerojatnosti javljanja nasilničkog ponašanja kod djece s niskim stupnjem samopouzdanja (Barboza i sur., 2009.). Nadalje, u opasnim susjedstvima javlja se pozitivna povezanost između odvažnosti i antisocijalnog ponašanja (Trentacosta i sur., 2009.) te veća povezanost roditeljskog kažnjavanja i vršnjačkog nasilja (Velki, 2012.), dok u sigurnim susjedstvima ovih povezanosti nema. Također je važan i ro-

\section{0 članci}


diteljski utjecaj, odnosno u situacijama kada su roditelji dobro upoznati s djetetovim aktivnostima, prosocijalno ponašanje je značajno negativno povezano s antisocijalnim ponašanjem (Trentacosta i sur., 2009.), dok je u situacijama kada roditelji vrše manji nadzor nad djetetom impulzivnost jače povezana uz tjelesno nasilničko ponašanje prema vršnjacima (Velki, 2012.). Nejednakost obiteljskih prihoda unutar razreda koji učenik pohađa također se pokazala kao značajan moderator pri čemu u razredima u kojima postoji velika nejednakost prihoda, dulje vrijeme provedeno uz medije, impulzivnost u dječaka te percepcija veće opasnosti susjedstva jače su povezane uz veći intenzitet vršnjačkog nasilja (Velki, 2012.).

Istraživanja pod ekološkim modelom utvrdila su i neke nove individualne prediktore vršnjačkog nasilja (npr. traženje zabave, dominantnost kao crta ličnosti, netolerancija različitosti, pseudoprijateljstvo i slab moralni autoritet nastavnika (Lee, 2010.), kao i neke prediktore s razine slabo istraženog mezosustava (npr. permisivnost roditelja i nastavnika (Barboza i sur., 2009.), nejednakost obiteljskih prihoda unutar razreda (Velki, 2012.). Konačno, s razine najteže mjerljivog makrosustava, značajnim prediktorom pokazao se kolektivizam (Lee, 2011.).

Usprkos svim navedenim prednostima, još uvijek postoji tek manji broj istraživanja koja su uzela u obzir sve prednosti primijene ekološkog modela na istraživanje vršnjačkog nasilja jer su takva istraživanja vrlo kompleksna, dugotrajna i financijski vrlo zahtjevna. Nadalje, iako ima novijih istraživanja čija su polazišta integrativne teorije nasilja, njihova metodologija još je manjkava. Često uzorci nisu reprezentativni (npr. spolno ili dobno homogeni ili nacionalno nereprezentativni, npr. Bowes i sur., 2009.; Trentacosta i sur., 2009.), pa je teško generalizirati dobivene rezultate. Nedovoljno su ispitane i neke populacije djece kao što su siromašna ili bogata djeca, djeca s teškoćama u učenju, djeca pojedinih seksualnih orijentacija i sl. Također, problem postoji i u nestandardiziranosti postupaka i nepostojanju univerzalnijih mjera za istraživanje ove pojave. $U$ istraživanjima se češće koriste neke metode mjerenja vršnjačkog nasilničkog ponašanja (npr. samoprocjene ili procjene od strane vršnjaka i nastavnika, a rijetko opažanje i vođenje dnevnika). Korištene upitničke mjere nasilničkog ponašanja vrlo su šarolike (npr. mjere antisocijalnog ponašanja gdje je nasilje među djecom samo jedan od čimbenika antisocijalnog ponašanja ili različiti jedno- ili višedimenzionalni upitnici nasilničkog ponašanja) što otežava usporedbu dobivenih nalaza pa tako i izvođenje zaključaka. Posebice se javlja problem oko operacionalizacije vršnjačkog nasilničkog ponašanja gdje se u pojedinim istraživanjima nasilje operacionalizira općenito, dok se u drugim istraživanjima dijeli na verbalno, tjelesno, relacijsko i dr. vrste vršnjačkog nasilničkog ponašanja što onemogućuje i uspoređivanje i zaključivanje o učestalosti nasilja, ali i njegovim korelatima. Nadalje, kod primjene ekološkog modela postoji nedosljednost oko svrstavanja nekih varijabli koje različiti autori svrstavaju na različite razine 
ekološkog sustava. Također, većina istraživanja pod ovim modelom provedena je na području SAD-a te nekoliko na području Azije (Izrael, Tajvan i Koreja) i jedno u Hrvatskoj (Velki, 2012.). Osim toga, nedostaju istraživanja kronosustavne razine modela, tj. istraživanja koja bi se osvrnula na promjene u pojedincu i okolini tijekom života i kako one utječu na nasilničko ponašanje (Hong i Espelage, 2012.). Za to su potrebna vrlo složena i skupa longitudinalna istraživanja.

Zaključno, potrebna su daljnja metodološki striktnija istraživanja nasilnog ponašanja među djecom koja bi bila provedena na reprezentativnim uzorcima, uz standardizirane instrumente i postupke mjerenja, koja bi razlučila različite vrste vršnjačkog nasilničkog ponašanja (npr. verbalno, tjelesno, relacijsko) te ispitala i nove oblike nasilničkog ponašanja, poput onog elektroničkog. Osim toga, potrebna je jasnija operacionalizacija varijabli (posebice razlikovanje vršnjačkog nasilja od vršnjačkog zlostavljanja) te se preporuča uporaba multivarijantnih analiza i ispitivanje medijatorskih i moderatorskih učinaka kontekstualnih činitelja nasilničkog ponašanja prema vršnjacima. Također je poželjno da se buduća istraživanja provedu i u nekim drugim kulturama, kako bi se provjerilo koliko se dosad dobiveni nalazi mogu generalizirati.

\section{LITERATURA}

1. Ajduković, D. \& Čorkalo Biruški, D. (2008). Caught between the ethnic sides: Children growing up in a divided post-war community. International Journal of Behavioral Development, 32 (4), 337-347.

2. Ahmed, E. \& Braithwaite, V. (2004). Bullying and victimization: Cause for concern for both families and schools. Social Psychology of Education, 7 (1), 35-54.

3. Aluede, O., Adeleke, F., Omoike, D. \& Afen-Akpaida, J. (2008). A review of the extent, nature, characteristics and effects of bullying behaviour in schools. Journal of Instructional Psychology, 35 (2), 151-158.

4. Anderson, C. A., Carnagey, N., Flanagan, M., Benjamin, A. J., Eubanks, J. \& Valentine, J. C. (2004). Violent video games: Specific effects of violent content on aggressive thoughts and behavior. Advances in Experimental Social Psychology, 36, 199-249.

5. Archer, J. (2004). Sex differences in aggression in real-world settings: A metaanalytic review. Review of General Psychology, 8 (4), 291-322.

6. Arcus, D. (2002). School shooting fatalities and school corporal punishment: A look at the states. Aggressive Behavior, 28 (3), 173-183.

7. Baldry, A. C. (2003). Bullying in schools and exposure to domestic violence. Child Abuse \& Neglect, 27 (7), 713-732. 
8. Baldry, A. C. \& Farrington, D. P. (2000). Bullies and delinquents: Personal characteristics and parental styles. Journal of Community and Applied Social Psychology, 10 (1), 17-31.

9. Barboza, G. E., Schiamberg, L. B., Oehmke, J., Korzeniewski, S. J., Post, L. A. \& Heraux, C. G. (2009). Individual characteristics and the multiple contexts of adolescent bullying: An ecological perspective. Journal of Youth Adolescence, 38 (1), 101-121.

10. Barrett, P. M., Rapee, R. M., Dadds, M. M. \& Ryan, S. M. (1996). Family enhancement of cognitive style in anxious and aggressive children. Journal of Abnormal Child Psychology, 24 (2), 187-203.

11. Berdondini, L. \& Smith, P. K. (1996). Cohesion and power in the families of children involved in bully/victim problems at school: An Italian replication. Journal of Family Therapy, 18 (1), 99-102.

12. Berthold, K. A. \& Hoover, J. H. (2000). Correlates of bullying and victimization among intermediate students in the Midwestern USA. School Psychology International, 21 (1), 65-78.

13. Björkqvist, K. (1994). Sex differences in physical, verbal, and indirect aggression: A review of recent research. Sex Roles, 30 (3-4), 177-188.

14. Bowers, L., Smith, P. K. \& Binney, V. (1994). Perceived family relationships of bullies, victims and bully/victims in middle childhood. Journal of Social and Personal Relationships, 11 (2), 215-232.

15. Bowes, L., Arseneault, L., Maughan, B., Taylor, A., Caspi, A. \& Moffit, T. E. (2009). School, neighborhood, and family factors are associated with children's bullying involvement: A nationally representative longitudinal study. Journal of American Academy of Child and Adolescent Psychiatry, 48 (5), 545-553.

16. Bowlby, J. (1979). The making and breaking of affectional bonds. London: Tavistock.

17. Bradshaw, C. P., Rodgers, C. R. R., Ghandour, L. A. \& Garbarino, J. (2009). Socialcognitive mediators of the association between community violence exposure and sggressive behavior. School Psychology, 24 (3), 199-210.

18. Buka, S. \& Earls, F. (1993). Early determinants of delinquency and violence. Health Affairs, 12 (4), 46-64.

19. Buljan Flander, G., Ćorić Špoljarić, R. \& Durman Marijanović, Z. (2007). Pojava nasilja među djecom s obzirom na spol, dob i prihvaćenost/odbačenost u školi. Društvena istraživanja, 16, 157-174.

20. Card, N. A. \& Hodegs, E. V. E. (2008). Peer victimization among schoolchildren: Correlations, causes, consequences, and consideration in assessment and intervention. School Psychology Quarterly, 23 (4), 451-461. 
21. Card, N. A., Stucky, B. D., Sawalani, G. M. \& Little, T. D. (2008). Direct and indirect aggression during childhood and adolescence: A meta-analytic review of gender differences, intercorrelations, and relations to maladjustment. Child Development, 79 (5), 1185-1229.

22. Cassidy, T. \& Taylor, L. (2005). Coping and psychological distress as a function of the bully victim dichotomy in older children. Social Psychology of Education, 8 (3), 249-262.

23. Cicchetti, D. \& Cohen, D. J. (2006). Developmental psychopathology: Risk, disorder, and adaptation. New Jersey: John Wiley \& Sons, Inc.

24. Cillessen, A. H. N. \& Borch, C. (2006). Developmental trajectories of adolescent popularity: A growth curve modelling analysis. Journal of Adolescence, 29, 935-959.

25. Crick, N. R. \& Bigbee, M. A. (1998). Relational and overt forms of peer victimization: A multi informant approach. Journal of Consulting and Clinical Psychology, 66(2), 337-347.

26. Curtner-Smith, M. E. (2000). Mechanisms by which family processes contribute to school-age boy's bullying. Child Study Journal, 30 (3), 169-186.

27. Cummings, E. M. \& Davies, P. T. (2002). Effects of marital discord on children: Recent advances and emerging themes in process-oriented research. Journal of Child Psychology and Psychiatry, 43 (1), 31-63.

28. Dake, J. A., Price, J. H. \& Telljohann, S. K. (2003). The nature and extent of bullying at school. Journal of School Health, 73 (5), 173-180.

29. Dijkstra, J. K., Lindenberg, S. \& Veenstra, R. (2007). Same-gender and crossgender peer acceptance and peer rejection and their relation with bullying and helping among preadolescents: Comparing predictions from genderhomophily and goal-framing approaches. Developmental Psychology, 43, 1377-1389.

30. Demaray, M. K. \& Malecki, C. K. (2003). Perceptions of the frequency and importance of social support by students classified as victims, bullies, and bully/ victims in an urban middle school. School Psychology Review, 32 (3), 471489.

31. Dooley, J. J., Pyzalski, J. \& Cross, D. (2009). Cyberbullying versus face-to-face bullying: A theoretical and conceptual review. Journal of Psychology, 217 (4), 182-188.

32. Duncan, R. D. (1999). Peer and sibling aggression: An investigation of intraand extrafamilial bullying. Journal of Interpersonal Violence, 14 (8), 871886.

33. Eisenberg, N., Damon, W. \& Lerner, R. M. (2006). Handbook of child psychology: Social, emotional, and personality development. New Jersey: John Wiley \& Sons, Inc. 
34. Elgar, F. J., Craig, W., Boyce, W., Morgan, A. M. \& Vella-Zarb, R. (2009). Income inequality and school bullying: Multilevel study of adolescents in 37 sountries. Journal of Adolescent Health, 45 (4), 351-359.

35. Eliot, M., \& Cornell, D. G. (2009). Bullying in middle school as a function of insecure attachment and aggressive attitudes. School Psychology International, 30 (2), 201-214.

36. Espelage, D. L., Bosworth, K. \& Simon, T. R. (2000). Examining the social context of bullying behaviors in early adolescence. Journal of Counseling and Development, 78 (3), 326-333.

37. Espelage, D. \& Horne, A. (2008). School violence and bullying prevention: From research based explanations to empirically based solutions. In: Brown, S. \& Lent, R. (eds.), Handbook of counseling psychology (4th edition). Hoboken, NJ: John Wiley and Sons, 588-606.

38. Espelage, D. L., Mebane, S. E. \& Swearer, S. M. (2004). Gender differences in bullying: Moving beyond mean level differences. In: Espelage, D. L. \& Swearer, S. M. (eds.), Bullying in American schools: A social-ecological perspective on prevention and intervention. Mahwah, NJ: Erlbaum, 15-35.

39. Espelage, D. L. \& Swearer, S. M. (2003). Research on school bullying and victimization: What have we learned and where do we go from here? School Psychology Review, 32 (3), 365-383.

40. Espelage, D. L. \& Swearer, S. M. (2004). Bullying in American schools: A social-ecological perspective on prevention and intervention. New Jersey: Lawrence Erlbaum Associates, Inc.

41. Espelage, D. L. \& Swearer, S. M. (2009a). Contributions of three social theories to understanding bullying perpetration and victimization among schoolaged youth. In: Harris, M. J. (ed.), Bullying, rejection and peer victimization: A social cognitive neuroscience perspective. New York: Springer Publishing Company, LLC, 151-170.

42. Espelage, D. L. \& Swearer, S. M. (2009b). A social-ecological model for bullying prevention and intervention. In: Harris, M. J. (ed.), Bullying, rejection, and peer victimization: A social cognitive neuroscience perspective. New York: Springer, 61-72.

43. Farmer, T.W., Leung, M. C., Pearl, R., Rodkin, P. C., Cadwallader, T. W. \& Van Acker, R. (2002). Deviant or diverse peer groups? The peer affiliations of aggressive elementary students. Journal of Educational Psychology, 94 (3), 611-620.

44. Farrington, D. P. (1997). Early prediction of violent and nonviolent youthful offending. European Journal on Criminal Policy and Research, 5 (2), 51-66.

45. Gentile, D. A., Lynch, P. J., Linder, J. R. \&Walsh, D. A. (2004). The effects of violent video game habits on adolescent aggressive attitudes and behaviors. Journal of Adolescence, 27 (1), 5-22. 
46. Gentile, D. A. \& Walsh, D. A. (2002). A normative study of family media habits. Journal of Applied Psychology, 23 (2), 157-178.

47. Gini, G., Albiero, P., Benelli, B. \& Altoè, G. (2007). Does empathy predict adolescents' bullying and defending behavior? Aggressive Behavior, 33 (5), 467476.

48. Gini, G. \& Pozzoli, T. (2009). Association between bullying and psychosomatic problems: A meta-analysis. Pediatrics, 123 (3), 1059-1065.

49. Givens, J. E. (2009). Does theory of mind mediate aggression and bullying in middle school males and females? Open Access Theses and Dissertations from the College of Education and Human Sciences. Paper 54.

50. Glew, G. M., Fan, M. Y., Katon, W., Rivara, F. P. \& Kernic, M. A. (2005). Bullying, psychosocial adjustment, and academic performance in elementary school. Archives of pediatrics \& adolescent medicine, 159 (11), 1026-1031.

51. Griffin, R. S. \& Gross, A. M. (2004). Childhood bullying: Current empirical findings and future directions for research. Aggression and Violent Behavior, 9 (4), 379-400.

52. Gullotta, T. P., Adams, G. R. \& Ramos, J. M. (2005). Handbook of adolescent behavioral problems: Evidence-based approaches to prevention and treatment. New York: Springer Science Business Media, Inc.

53. Hanish, L. D., \& Guerra, N. G. (2000). The roles of ethnicity and school context in predicting children's victimization by peers. American Journal of Community Psychology, 28 (2), 201-223.

54. Hanish, L. D., Kochenderfer-Ladd, B., Fabes, R. A., Martin, C. L. \& Denning, D. (2004). Bullying among young children: The influence of peers and teachers. In: Espelage, D. L. \& Swearer, S. M. (eds.), Bullying in American schools: A social-ecological perspective on prevention and intervention. Mahwah, NJ: Lawrence Erlbaum Associates, 141-159.

55. Harel-Fisch, Y., Walsh S. D., Fogel-Grinvald, H., Amitai, G., Pickett, W., Molcho, M., Due, P., Gaspar de Matos, M. \& Craig, W. (2011). Negative school perceptions and involvement in school bullying: $A$ universal relationship across 40 countries. Journal of Adolescence, 34 (4), 639-652.

56. Hazler, R., Miller, D., Carney, J. \& Green, S. (2001). Adult recognition of school bullying situations. Educational Research, 43 (7), 133-147.

57. Holt, M. K. \& Keyes, M. A. (2004). Teachers' attitudes toward bullying. In: Espelage, D. L. \& Swearer, S. M. (eds.), Bullying in American schools: A social-ecological perspective on prevention and intervention. Mahwah, $\mathrm{NJ}$ : Erlbaum, 121-139.

58. Hong, J. S. \& Espelage, D. L. (2012). A review of research on bullying and peer victimization in school: An ecological systems analysis. Aggression and Violent Behavior, 17 (4), 311-322. 
T. Velki, G. Kuterovac Jagodić: Individualni i kontekstualni činitelji dječjega...

59. Ilišin, V. (2003). Mediji u slobodnom vremenu djece i komunikacija o medijskim sadržajima. Medijska istraživanja, 9 (2), 9-34.

60. Kasen, S., Berenson, K., Cohen, P. \& Johnson, J. G. (2004). The effects of school climate on changes in aggressive and other behaviors related to bullying. In: Espelage, D. L. \& Swearer, S. M. (eds.), Bullying in American schools: A social-ecological perspective on prevention and intervention. Mahwah, $\mathrm{NJ}$ : Erlbaum, 187-210.

61. Kashani, J. H., Deuser, W. \& Reid, J. C. (1991). Aggression and anxiety: A new look at an old notion. Journal of the American Academy of Child and Adolescent Psychiatry, 30 (2), 218-223.

62. Kellaghan, T., Sloane, K., Alvarez, B. \& Bloom, B. S. (1993). The home environment and school learning: Promoting parental involvement in the education of children. San Francisco: Jossey-Bass.

63. Khoury-Kassabri, M., Benbenishty, R., Avi Astor, R. \& Zeira, A. (2004). The contributions of community, family and school variables to student victimization. American Journal of Community Psychology, 34 (3-4), 187-204.

64. Knight, G. P., Guthrie, I. K., Page, M. C. \& Fabes, R. A. (2002). Emotional arousal and gender differences in aggression: A meta-analysis. Aggressive Behavior, 28, 266-393.

65. Knutson, J. F. (1995). Psychological characteristics of maltreated children: Putative risk factors and consequences. Annual Reviews of Psychology, 46, 401-431.

66. Kõiv, K. (2012). Attachment styles among bullies, victims and uninvolved adolescents. Psychology Research, 2 (3), 160-165.

67. Kokkinos, C. M. (2013). Bullying and victimization in early adolescence: Associations with attachment style and perceived parenting. Journal of School Violence, 12 (2), 174-192.

68. Kukaswadia, A. A. (2009). Social consequences of obesity among Canadian youth. Unpublished master's thesis, Queen's University, Kingston, Ontario, Canada.

69. LaFontana, K. \& Cillessen, A. H. N. (2002). Children's perceptions of popular and unpopular peers: A multimethod assessment. Developmental Psychology, 38 (5), 635-647.

70. Laub, J. H. \& Lauritsen, J. L. (1998). The interdependence of school violence with neighborhood and family conditions. In: Elliott, D. S., Hamburg, B. A. \& Williams, K. R. (eds.), Violence in American schools. New York: Cambridge University Press, 127-155.

71. Lee, C. H. (2010). Personal and interpersonal correlates of bullying behaviors among Korean middle school students. Journal of Interpersonal Violence, 25 (1), 152-176. 
72. Lee, C. H. (2011). An ecological systems approach to bullying behaviors among middle school student sin the United States. Journal of Interpersonal Violence, 26 (8), 1664-1693.

73. Majvald Bjedov, I. (2011). Međuvršnjačko nasilje i depresivnost u djece osnovnoškolske dobi. Neobjavljeni diplomski rad. Sveučilište u Zagrebu, Filozofski fakultet, Zagreb.

74. Marini, Z. A., Dane, A. V. \& Bosacki, S. L. (2006). Direct and indirect bully-victims: Differential psychosocial risk factors associated with adolescents involved in bullying and victimization. Aggressive Behavior, 32 (6), 551-569.

75. Menesini, E., Camodeca, M. \& Nocentini, A. (2010). Bullying among siblings: The role of personality and relational variables. British Journal of Developmental Psychology, 28 (4), 921-939.

76. Murray-Harvey, R., Slee, P. T. \& Taki, M. (2010). Comparative and cross-cultural research on school bullying. In: Jimerson, S. R., Swearer, S. M. \&. Espelage, D. L. (eds.), Handbook of bullying in schools: An international perspective. New York: Taylor i Francis Group, 35-47.

77. Nansel, T. R., Overpack, M., Pilla, R. S., Ruan, W. J., Simons-Morton, B. \& Scheidt, P. (2001). Bullying behaviors among US youth. JAMA, 285 (16), 2094-2100.

78. Nesdale, D. \& Naito, M. (2005). Individualism-collectivism and the attitudes to school bullying of Japanese and Australian students. Journal of Cross Cultural Psychology, 36, 1-20.

79. Newman, R. S., Murray, B. \& Lussier, C. (2001). Confrontation with aggressive peers at school students' reluctance to seek help from the teacher. Journal of Educational Psychology, 93 (2), 398-410.

80. Nikiforou, M., Georgiou, S. N. \& Stavrinides, P. (2013). Attachment to parents and peers as a parameter of bullying and victimization. Journal of Criminology, 1, 1-9.

81. Olweus, D. (1994). Annotation: Bullying at school: Basic facts and effects of a school based intervention program. Journal of Child Psychology and Psychiatry, 35 (7), 1171-1190.

82. Olweus, D. (1998). Nasilje među djecom u školi: Što znamo i što možemo učiniti. Zagreb: Školska knjiga.

83. Olweus, D. (2010). Understanding and researching bullying: Some critical issues. In: Jimerson, S. R., Swearer, S. M. \& Espelage, D. L. (eds.), Handbook of bullying in schools: An international perspective. New York: Taylor i Francis, 9-33.

84. Olweus, D. \& Limber, S. (1999). The bullying prevention program. In: Elliott, D. S. (ed.), Blueprints for violence prevention. Boulder, CO: Regents of the University of Colorado, 1-79. 
85. O'Moore, M., Kirkham, C. \& Smith, M. (1998). Bullying in schools and Ireland: A nationwide study. Irish Educational Studies, 17, 254-271.

86. Orpinas, P. \& Horne, A. M. (2006a). Risk and protective factors for bullying and aggression. In: Orpinas, P. \& Horne, A. M. (eds.), Bullying prevention: Creating a positive school climate and developing social competence. Washington, DC, American Psychological Association, 33-53.

87. Orpinas, P. \& Horne, A. M. (2006b). Theoretical perspectives on bullying and aggression. In: Orpinas, P. \& Horne, A. M. (eds.), Bullying prevention: Creating a positive school climate and developing social competence. Washington, DC, American Psychological Association, 55-76.

88. Orpinas, P., Kelder, S., Frankowski, R., Murray, N., Zhang, Q. \& McAlister, A. (2000). Outcome evaluation of a multicomponent violence-prevention program for middle schools: The Students for peace project. Health Education Research, 15 (1), 45-58.

89. Özkan, Y. \& Gökçearslan Çifci, E. (2009). The effect on empathy level on peer bullying in schools. Humanity \& Social Science Journal, 4 (1), 31-38.

90. Park, K. \& Son, H. (1998). A study on wangtta (bullying) among student. Seoul: Korean Institute of Educational Development.

91. Parkhurst, J. T. \& Hopmeyer, A. G. (1998). Sociometric popularity and peer-perceived popularity: Two distinct dimensions of peer status. Journal of Early Adolescence, 18 (2), 125-144.

92. Peguero, A. A. (2009). Victimizing the children of immigrants: Latino and Asian American student victimization. Youth and Society, 41 (2), 186-208.

93. Pellegrini, A. D., Bartini, M. \& Brooks, F. (1999). School bullies, victims, and aggressive victims: Factors relating to group affiliation and victimization in early adolescence. Journal of Educational Psychology, 91 (2), 216-224.

94. Pellegrini, A. D. \& Long, J. D. (2002). A longitudinal study of bullying, dominance, andvictimization during the transition from primary school through secondary school. British Journal of Developmental Psychology, 20 (2), 259-80.

95. Perren, S. \& Hornung, R. (2005). Bullying and delinquency in adolescence: Victims' and perpetrators' family and peer relations. Swiss Journal of Psychology, 64 (1), 51-64.

96. Perry, D. G., Williard, J. C. \& Perry, L. C. (1990). Peers' perceptions of the consequences that victimized children provide aggressors. Child Development, 61 (5), 1310-1325.

97. Peterson, J. S. \& Ray, K. E. (2006). Bullying and the gifted:Victims, perpetrators, prevalence, and effects. Gifted Child Quarterly, 50 (2), 148-168. 
98. Pettit, G. S., Bates, J. E., Dodge, K. A. \& Meece, D. W. (1999). The impact of afterschool peer contact on early adolescent externalizing problems is moderated by parental monitoring, perceived neighborhood safety, and prior adjustment. Child Development, 70, 768-778.

99. Profaca, B., Puhovski, S. \& Luca Mrđen, J. (2006). Neke karakteristike pasivnih i provokativnih žrtava nasilja među djecom. Društvena istraživanja, 16 (3), 575-590.

100. Pšunder, M. \& Cvek, M. (2012). Kako učenici doživljavaju medijsko nasilje. Informatologia, 45 (1), 1-13.

101. Rajhvajn Bulat, L. \& Ajduković, M. (2012). Obiteljske i psihosocijalne odrednice vršnjačkog nasilja među mladima. Psihologijske teme, 21(1), 167-194.

102. Rigby, K. (1993). School children's perceptions of their families and parents as a function of peer regulations. The Journal of Genetic Psychology, 154 (4), 501-513.

103. Rigby, K. (2002). A meta-evaluation of methods and approaches to reducing bullying in pre-schools ane early primary school in Australia. Canberra: Attorney-General's Department.

104. Rivers, I., Duncan, N. \& Besag, V. E. (2007). Bullying. Handbooks for educators and parents. Westport, Connecticut, London: Praeger Publisher.

105. Rodkin, P. C. (2002). I think you're cool: Social status and group support for aggressive boys and girls. Invited address to the 8th Triannual Meeting of the Northeast Social Development Consortium, New York, NY.

106. Rodkin, P. C., Farmer, T. W., Pearl, R. \& Van Acker, R. (2000). Heterogeneity of popular boys: Antisocial and prosocial configurations. Developmental Psychology, 36, 14-24.

107. Rose, C. A., Monda-Amaya, L. E. \& Espelage, D. L. (2011). Bullying perpetration and victimization in special education: A review of the literature. Remedial and Special Education, 32 (3), 114-130.

108. Rumberger, R. W. (1995). Dropping out of middle school: A multilevel analysis of students and schools. American Educational Research Journal, 32 (3), 583-625.

109. Sabri, B., Hong, J. S., Campbell, J. C. \& Cho, H. (2013). Understanding children and adolescents' victimizations at multiple levels: An ecological review of the literature. Journal of Social Service Research, 39 (3), 322-334.

110. Samara, M. \& Smith, P. K. (2008). How schools tackle bullying, and the use of whole school policies: Changes over the last decade. Educational Psychology, 28 (6), 663-676.

111. Saylor, C. F. \& Leach, J. B. (2009). Perceived bullying and social support in students accessing special inclusion programming. Journal of Developmental and Physical Disabilities, 21, 69-80. 
112. Schwartz, D., Dodge, K. A., Pettit, G. S. \& Bates, J. E. (1997). The early socialization of aggressive victims of bullying. Child Development, 68 (4), 665-675.

113. Shakoor, S., Jaffeel, S. R., Bowes, L., Ouellet-Morin, I., Andreou, P., Happé, F., Moffitt, T. E. \& Arseneault, L. (2012). A prospective longitudinal study of children's theory of mind and adolescent involvement in bullying. Journal of Child Psychology and Psychiatry, 53 (3), 254-261.

114. Shields, A. \& Cicchetti, D. (2001). Parental maltreatment and emotion dysregulation as risk factors for bullying and victimization in middle childhood. Journal of Clinical Child Psychology, 30 (3), 349-363.

115. Shin, Y. (2000). A comparison study in bullying of middle school students: Focus on social environment. Seoul, South Korea: Joongang University.

116. Slee, P. T. (2003). School bullying in Australia: Developments in understanding and intervention initiatives. Paper presented at the Oxford Kobe Education Seminar, Measures to reduce bullying in schools. Kobe, Japan: Kobe Institute.

117. Snyder, J., Horsch, E. \& Childs, J. (1997). Peer relationships of young children: Affiliative choices and the shaping of aggressive behavior. Journal of Clinical Child Psychology, 26, 145-156.

118. Spriggs, A. L., lannotti, R. J., Nansel, T. R. \& Haynie, D. L. (2007). Adolescent bullying involvement and perceived family, peer and school relations: Commonalities and differences across race/ethnicity. Journal of Adolescent Health, 41 (3), 283-293.

119. Stassen Berger, K. (2007). Update on bullying at school: Science forgotten? Developmental Review, 27 (1), 90-126.

120. Stevens, V., De Bourdeaudhuij, I. \& Van Oost, P. (2002). Relationship of the family environment to children's involvement in bully/victim problems at school. Journal of Youth and Adolescence, 31 (6), 419-428.

121. Sušac, N., Rimac, I. \& Ajduković, M. (2012). Epidemiološko istraživanje nasilja među djecom. Rad prikazan u sklopu nacionalne konferencije Raširenost nasilja nad djecom u obitelji i među vršnjacima. 22. i 23. ožujka, 2012., Zagreb, Hrvatska.

122. Sutton, J., Smith, P. K. \& Swettenham, J. (1999). Bullying and 'theory of mind': A critique of the 'social skills deficit' view of anti-social behaviour. Social Development, 8 (1), 117-127.

123. Swearer, S. M., Espelage, D. L., Vaillancourt, T. \& Hymel, S. (2010). What can be done about school bullying? Educational Researcher, 39 (1), 38-47.

124. Swearer, S. M., Song, S. Y., Cary, P. T., Eagle, J. W. \& Mickelson, W. T. (2001). Psychosocial correlates in bullying and victimization: The relationship between depression, anxiety, and bully/victim status. Journal of Emotional Abuse, $2(2-3), 95-121$. 
125. Tai, M. (2001). Treatments for bullying and their effects. In: Morita, Y. (ed.), Cross-national Study of Bullying. Tokyo: Kaneko Shyobou, 123-144.

126. Trentacosta, C. J., Hyde, L. W., Shaw, D. S. \& Cheong, J. (2009). Adolescent dispositions for antisocial behavior in context: The roles of neighborhood dangerousness and parental knowledge. Journal of Abnormal Psychology, 118 (3), 564-575.

127. Veenstra, R., Lindenberg, S., Oldehinkel, A. J., De Winter, A. F., Verhulst, F. C. \& Ormel, J. (2005). Bullying and victimization in elementary schools: A comparison of bullies, victims, bully/victims, and uninvolved preadolescents. Developmental Psychology, 41 (4), 672-682.

128. Vejmelka, L. (2012). Neke determinante vršnjačkog nasilja u adolescenciji. Ljetopis socijalnog rada, 19 (2), 215-240.

129. Velki, T. (2010). Pojavnost nasilja među srednjoškolcima. Zbornik radova sa skupa Nasilje nad djecom i među djecom (2008), 267-282.

130. Velki, T. (2012). Provjera ekološkog modela dječjega nasilničkoga ponašanja prema vršnjacima. Neobjavljeni doktorski rad. Sveučilište u Zagrebu, Filozofski fakultet, Zagreb.

131. Wang, J., lannotti, R. J. \& Nansel, T. R. (2009). School bullying among adolescents in the United States: Physical, verbal, relational, and cyber. Journal of Adolescent Health, 45 (4), 368-375.

132. Wei, H. S., Williams, H. W., Chen, J. K. \& Chang, H. Y. (2010). The effects of individual characteristics, teacher practice, and school organizational factors on students' bullying: A multilevel analysis of public middle schools in Taiwan. Children and Youth Services Review, 32, 137-143.

133. Williams, K. (2011). Bullying behaviors and attachment styles. Electronic Theses \& Dissertations. Paper 444.

134. Wolke, D. \& Skew, A. J. (2012). Family factors, bullying victimisation and wellbeing in adolescents. Longitudinal and Life Course Studies, 3 (1), 101-119.

135. Woods, S. \& Wolke, D. (2004). Direct and relational bullying among primary school children and academic achievement. Journal of School Psychology, 42 (2), 135-155.

136. Woodward, E. H. \& Gridina, N. (2000). Media in the home in 2000: The fifth annual survey of parents and children. Philadelphia: Annenberg Public Policy Center, University of Pennsylvania.

137. Zimmerman, F. J., Glew, G. M., Christakis, D. A. \& Katon, W. (2005). Early cognitive stimulation, emotional support, and television watching as predictors of subsequent bullying among grade-school children. Archives of Pediatric Adolescent Medicine, 159, 384-388. 
T. Velki, G. Kuterovac Jagodić: Individualni i kontekstualni činitelji dječjega...

Tena Velki

Faculty of Teacher Education

University of J. J. Strossmayer Osijek

Gordana Kuterovac Jagodić

Faculty of Humanities and Social Sciences

University of Zagreb

\section{INDIVIDUAL AND CONTEXTUAL FACTORS OF PEER VIOLENCE}

\section{SUMMARY}

Peer violence has been increasing among children and has become a significant problem in many societies. Numerous studies of peer violence and bullying seek the explanations of this phenomenon in classical theories of aggression treating bullying as a form of aggressive behaviour. However, recent research frequently finds their theoretical starting point in a newer and more comprehensive integrative model of peer violence. Those models rely on classical theories but, combining them and taking into account a number of different factors contribute significantly to the explanation of the emergence of children's violent behaviour towards their peers. One of the commonly-used integrative theories is Bronfenbrenner's ecological model that has induced a number of studies of behavioural, psychological and biological characteristics of individuals but also, the interactions between the individual and environment and the interactions between the different levels of context. In this paper, based on an extensive literature review, and in light of the ecological model, we are trying to systematise insofar established facts about factors that are associated with the appearance of peer violence and, to provide a critical review of the research, with special emphasis on those that were guided by an ecological approach. A significant shift in the application of the theoretical framework and the use of improved methodology and advanced statistical analysis has been observed, very few studies take into account all of these aspects. Most researchers focus on one or two levels of ecological models and simple methodology neglecting complexity of the peer violence problems. Future studies should take into account advances in theoretical and methodological knowledge in research of peer violence.

Key words: peer violence, ecological model, individual characteristics, contextual characteristics. 
